\title{
Connection Between Structural Changes and Electrical Parameters of Pea Root Tissue Under Anoxia
}

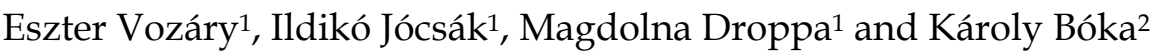 \\ ${ }^{1}$ Corvinus University of Budapest \\ 2Eötvös Lóránd University \\ Hungary
}

\section{Introduction}

Anaerobiosis in plants is common. Plant species have different sensitivity to oxygen deprivation. Plants evolved anatomical or metabolic adaptations to compensate for flooded conditions are called wetland plants. Most agricultural plants tolerate waterlogging poorly and can be categorized as flood-tolerant (wheat, maize, oat, potato) or flood-sensitive (pea, tomato, soybean) plants.

The most immediate effect of anaerobic soil conditions on plants is a reduction in aerobic respiration in roots. Root cells switch to anaerobic respiration which is much less efficient than aerobic respiration. Under normal aerobic conditions 30 to $32 \mathrm{~mol}$ ATP are produced per hexose sugar by oxidative phosphorylation, citric acid cycle and glucolysis, whereas at anoxic conditions only 2 mol ATP per mol hexose sugar can be produced by glucolysis, which finally leads to nutrient deficiencies (Niki \& Gladish, 2001). The principal end products of glycolysis are lactate and ethanol. Lactate production lowers the cytoplasmic $\mathrm{pH}$ and in flood-sensitive species, as pea the cytoplasmic acedosis causes cell death (Tuba \& Csintalan, 1992).

In the oxygen-lack circumstance not only the metabolism of root, but that of the whole plant is sustained, because the root is not able to take up and to transfer the nutrients. There is generated ions-lack in leaves and in sprouts. In plants under long-time flood there can be appeared symptoms pointing on drought, too. Water permeability of root is decreased causing the decrease of water potential, even at closed stoma (Tuba \& Csintalan, 1992).

In those plants, that genetically do not have aerenchymas, sudden flood increases the activity of cellulases and this leads to aerenchima formation in roots and vascular cavities may appear in the vascular cylinder (Niki \& Gladish, 2001; Grichko \& Glick, 2001).

Sarkar et al. (2008) investigated the vascular cavity formation induced by sudden flooding in pea primary roots. In the central vascular cavity of pea primary roots undifferentiated parenchymatous cells degenerate under hypoxic conditions created by flooding at temperatures higher, than $15^{\circ} \mathrm{C}$. They form a long vascular cavity that seems to provide a conduit for longitudinal oxygen transport in the roots. Specific changes in the cell wall 
ultrastructure were accompanied with cytoplasmic and organellar degradation in the cavityforming roots. The degenerating cells had thinner primary cell walls, less electron-dense middle lamellae, and less abundant cell wall homogalacturonans in altered patterns compared to healthy cells of root. Cellular breakdown and changes in wall ultrastructure, however, remained confined to cells within a $50 \mu \mathrm{m}$ radius around the root centre, even after full development of cavity. Cells farther away maintained cellular integrity and had signs of wall synthesis, perhaps from tight regulation of wall metabolism over short distances. Cold, flooded or warm, nonflooded conditions do not induce vascular cavity formation, but can also induce variations in cell wall structure (Sarkar et al., 2008).

Electrical impedance is a complex resistance in the presence of alternating current, and can be a useful tool for investigation of structural characteristics of solid materials and also animal, plant and human tissue (Macdonald, 1987; Grimnes \& Martinsen, 2000). The electrical impedance spectrum of living tissue in low frequency range - from $10 \mathrm{~Hz}$ up to 10 $\mathrm{MHz}$ - can be described with various model circuits, elements of which can represent the electrical resistance and capacitance of different cellular structures (Hayden et al., 1968; Privé \& Zhang, 1996; Zhang \& Willison, 1993).

Different models have been created in order to approximate cellular compartments: Hayden model, in which the apoplasmic $\left(\mathrm{R}_{a}\right)$ and symplasmic $\left(\mathrm{R}_{s}\right)$ resistance is calculated (Hayden et al., 1968); the modified Hayden model also considers the cell membrane capacitance (Vozáry et al., 1999); and the "double shell model" includes the interior resistance of vacuoles and the plasma membrane capacitance as well (Zhang \& Willison, 1991).

Several stress-induced alterations have already been followed in plants by electrical impedance spectroscopy. During dehydration of potato (Solanum tuberosum L.) and carrot (Daucus carota) pieces, the ratio between $R_{s}$ and $R_{a}$ decreases (Toyoda et al., 1994). Cold acclimation was found to enhance the impedance of alfalfa (Medicago sativa L.) (Hayden et al., 1968). Correlation was found between the phase angle data and the rate of aging of plasma membrane in the control and in calcium and phosphorous deficient subterranean clover (Trifolium subterraneum L.) (Greenham et al., 1972). Membrane injuries caused by temperature extremities can also be followed by impedance spectroscopy (Repo et al., 2000). A linear correlation was found between intracellular resistance and frost hardening capability of Scots pine (Pinus sylvestris L.) (Repo et al., 2000). Prediction of mechanical destruction in apple tissue under the skin is also possible with impedance spectroscopy (Vozáry et al., 1999; Vozáry \& Benkő, 2010). The parameters of impedance spectrum can be used in describing the drying process of apple slices (Mészáros et al., 2005), or withering of lettuce (Vozáry et al., 2009). The germinability of soybean and snap bean seed can be predicted using the impedance parameters (Vozáry et al., 2007).

On the basis of results described in preceding paragraphs, structural changes caused by various environmental effects can be detected by electrical impedance spectroscopy, therefore the detection of structural changes as a consequence of anoxia caused by flooding of plants can also be realised. The impedance spectroscopy analysis requires neither physical nor chemical preparation of investigated plants. The measurement of an impedance spectrum takes time no more some minutes. The fastness and the simplicity of this method take competitive it compared with new microscopic techniques. This technique gives permission for detection of early changes both in physiological state and in structure following the flooding - the appearance of total lack of oxygen. The impedance 
spectroscopy can also be used to detect the effect of flooding in very young seedlings, when other techniques - for example fluorescence induction spectroscopy can not be realized because of the lack of fully opened leaves.

The aim of this work is to summarize the change of impedance parameters in root tissue of pea seedling of various ages under flooding stress, in anoxic condition (total lack of soil oxygen). There can be expected an alteration of the resistance in both apoplasmic and symplasmic electrolyte systems and the membrane capacitance by which stress development can be followed by electrical impedance spectroscopy that is a fast method carried out without the grinding and processing of plant tissues.

\section{Materials and method}

The flood-caused changes in impedance parameters of three and ten days old pea seedlings, which easily grow in artificial circumstances, were followed up to eleven days and up to ten days, respectively. The structural changes in the case of three days old seedlings were detected by light microscopy, too.

\subsection{Plant material and growth conditions}

Seeds of pea (Pisum sativum L. cv. 'Debreceni világos') were surface sterilized in 3\% (w/v) sodium hypochlorite, then rinsed several times. Then seeds were soaked in distilled water for six hours after which they were sowed into a tray filled with formerly sterilized damp perlite. Germination took place in a dark room in room temperature. Two serial of experiments were executed: 1 . three days old and 2. ten days old seedlings were transferred to half Hoagland solution. Half Hoagland solution consist of $\mathrm{Ca}(\mathrm{NO})_{3} \cdot 4 \mathrm{H}_{2} \mathrm{O}(2.17 \mathrm{mM})$, $\mathrm{KNO}_{3}(4.89 \mathrm{mM}), \mathrm{KH}_{2} \mathrm{PO}_{4}(1.5 \mathrm{mM}), \mathrm{MgSO}_{4} \cdot 7 \mathrm{H}_{2} \mathrm{O}(0.134 \mathrm{mM})$, Na-FeEDTA $(0.134 \mu \mathrm{M})$, $\mathrm{H}_{3} \mathrm{BO}_{4}(69.3 \mu \mathrm{M}), \mathrm{MnSO}_{4}(13.6 \mu \mathrm{M}), \mathrm{ZnSO}_{4} \cdot 2 \mathrm{H}_{2} \mathrm{O}(1.1 \mu \mathrm{M}), \mathrm{NaMoO}_{4} \cdot 2 \mathrm{H}_{2} \mathrm{O}(0.15$ $\mu \mathrm{M}), \mathrm{CuSO}_{4} \cdot 5 \mathrm{H}_{2} \mathrm{O}(0.48 \mu \mathrm{M})$ (Hoagland \& Arnon, 1950), which was changed every third day. The seedlings were grown in a Conviron S10 type phytothrone $\left(120 \mu \mathrm{M} \mathrm{m}^{-2} \cdot \mathrm{s}^{-1}\right.$ light intensity, $22-23^{\circ} \mathrm{C}, 85 \%$ relative humidity). The duration of light was $16 \mathrm{~h}$.

In the case of three days old seedlings there were two serial experiments without and with aerating the hydroponic solution. The flooded ten days old seedlings were not aerated. The length of root was measured for three days old seedlings flooded, aerated and only flooded.

In each experiment 15-20 seedlings were investigated, and experiments were repeated three times. The average values with standard deviation are shown in graphs.

\subsection{Morphological and light microscopic investigations}

Morphological (root lengths) and tissue structure evaluation were carried out in parallel for each experiment with three days old seedlings. For light microscopic investigations, samples were collected from the epicotyl and the upper part of the primary root of the seedlings and fixed in $4 \%$ formaldehyde solution (in $0.1 \mathrm{M}$ phosphate buffer, $\mathrm{pH} 7.2$ ). After dehydration through a series of increasingly concentrated solutions of ethanol, as an intermediary solvent, benzene was used before paraffin embedding. Sections (10 $\mu \mathrm{m}$ thick) were prepared with a Leitz Wetzlar microtome and mounted on egg albumin mountant covered glass slides. Roots and epicotyls of 5 plants per treatment were sampled, from each of them 4 
slides were prepared (25 sections per slides). Sections were stained with Bismarck brown and malachite green (Ruzin, 1999). Micrographs were taken with an Opton III photomicroscope.

Vascular cylinder of the pea primary root consists of tracheary elements mainly. Their number and size are influenced alike by developmental and stress-induced processes (Luxova, 1995; Iijima \& Kato, 2007). The state of the vascular cylinder can be characterised by the numbers of tracheae and size of the vascular cylinder, so the product of the tracheae number (T) and the diameter of the vascular cylinder (VC) was calculated as an informative parameter of the VC wideness and cell size correlation. The average of $\mathrm{VC}$ diameter in a root sample was established from the maximal and the minimal diameter measured in it. Measurement of VC perimeter or estimation of square area of VC and tracheary elements are time-consuming and not more precise then product from $\mathrm{T}$ and $\mathrm{VC}$, which is simplified but represents the main factors influencing VC structure. Vascular cavity formation was not measured separately because its presence is indicated by the product of VC and T.

\subsection{Electrical impedance measurements}

\subsubsection{Theory of electrical impedance spectroscopy}

The application of a monochromatic voltage signal at single frequency to a sample results in a current of the same frequency. If the sample has no capacitance or inductance, the phase of the current is the same as that of the voltage. However, if the sample has any capacitive reactance, a phase shift does occur. The electrical impedance $(Z)$ of a sample is the quotient of the alternating voltage $\left(U=U_{0} \sin \omega t+j U_{0} \cos \omega t\right)$ across the sample and the alternating current $I=I_{o} \sin (\omega t+\varphi)+j I_{o} \sin (\omega t+\varphi)$ through the sample. $U_{o}$ and $I_{0}$ are the peak values of voltage and current and $U$ and $I$ are the complex values of voltage and current at time $t$. $j=\sqrt{-1}$ is the imaginary operator and $\omega=2 \pi f$, where $f$ is the measuring frequency. Because of this phase shift $(\varphi)$ between these two sinusoidal quantities, the quotient $Z=U / I$ must be handled as a complex number, having both real $(R)$ and imaginary $(X)$ parts:

$$
Z=\frac{U}{I}=|Z| \cdot \cos \varphi+j|Z| \cdot \sin \varphi=R+j X
$$

Therefore, impedance can be plotted in the complex plane, which, in this case, is also called a Wessel diagram (Grimnes \& Martinsen, 2000; Macdonald, 1987). $|Z|$ and $\varphi$ are the magnitude and the phase angle of impedance, respectively.

The electrical impedance spectrum is the distribution of impedance values in the frequency range of an applied alternating current. The intercellular (apoplastic) part and the intracellular (symplastic) part of living tissue has mainly resistive characteristics, while the cell membrane have capacitance with very low conductance. In living tissues, an alternating electric field causes polarization and relaxation of dipoles. At low frequency, the current passes through the apoplastic space of tissue where ions are the main current carriers. Cell membranes and other interfacial layers become conductive with increasing frequency, with the apparent current being dependent on the permittivity of interfacial layers (Pething \& Kell, 1987). Accordingly, symplastic space becomes more conductive at higher frequencies. At high frequencies the symplastic and the apoplastic resistance form a parallel circuit (Zhang \& Willison, 1991; Grimnes \& Martinsen, 2000). 
In some instances of other studies, the impedance spectrum measured on biological tissues has been modeled with equivalent circuits. In the simplest case, the measured impedance of tissue consisting of uniform, homogeneous cells can be described with a lumped model containing discrete resistors and capacitors (Harker \& Maindonald, 1994; Zhang \& Willison, 1991; Vozáry et al., 1999). In general, these resistors and capacitors can represent the resistance and capacitance of cell compartments, and the electrical behavior of tissue can be explained using the properties of these models (Grimnes \& Martinsen, 2000). When biological tissues are non-homogeneous, distributed models are more appropriate (Repo \& Zhang, 1993; Vozáry et al., 2007). If the sample under investigation contains several components having a variety of differing structures, then the measured impedance is the resultant of each structure. The equivalent lumped model of such a structure contains too many parameters for a practical mathematical description. However, these resultant impedance characteristics can be modeled using distributed elements containing fewer parameters. The trade-off, however, is that these parameters taken individually do not necessarily represent actual anatomical structures of sample tissue.

\subsubsection{Measurement of electrical impedance spectra}

The impedance spectra were measured with a two-pin electrode arrangement. The thickness and the length of the gold-plated copper pins were $0.35 \mathrm{~mm}$ and $6 \mathrm{~mm}$, respectively. The electrodes were connected to BNC jacks by copper wires with Teflon isolation and the BNC jacks were joined to the LCR meter by a special $1 \mathrm{~m}$ length shielded cable (HP-16048A). The electrode spacing was $2 \mathrm{~mm}$.

The impedance spectra were measured in roots tissues. The root was punctured with electrodes about $2 \mathrm{~cm}$ and $3 \mathrm{~cm}$ below the basis along the longitudinal axis for three and ten days old seedlings, respectively. Impedance spectrum of three days old seedlings was measured before flooding and 2, 4, 8 and 11 days after flooding. For the ten days old seedlings the impedance spectrum was determined four days daily before flooding and 1, 3 , 6, 12, 24, 48, 96 and 240 hours after flooding.

The magnitude and phase angle of electrical impedance between the two pins were measured by a HP 4284A Precision LCR meter at 100 frequencies in the frequency range from $30 \mathrm{~Hz}$ up to $1 \mathrm{MHz}$. The input voltage level of the sine signal was $1 \mathrm{~V}$. The LCR meter was connected to a computer via a GPIB interface. Data collection was performed by a QBasic program. Open (measuring air) and short (measuring short circuit) correction were applied to minimize measurement errors: stray capacitance and inductance as it is recommended by the manufacturer of the LCR meter (Honda, 1989).

\subsubsection{Modelling of electrical impedance spectra}

The corrected impedance spectra were approached with the modified Hayden model (Fig. 1) using the complex least square method. The modified Hayden model is a relatively simple so called explanatory (Grimdes \& Martinsen, 2000) - model of plant tissue. It contains the resistance of apoplasm (intercellular part), the resistance of symplasm (intracellular part) and the complex capacitance of cell membrane. This model describes the two parallel ways of current in living tissue: one of them is between the cells and other through the cell membrane and inside of cells. 


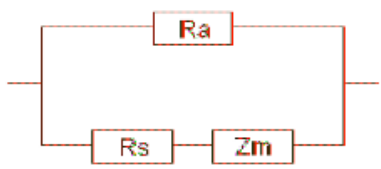

Fig. 1. Modified Hayden model. $R_{a}, R_{s}$ are resistance of apoplasm (intercellular space) and symplasm (intracellular space) and $Z_{m}$ is the impedance of membrane.

The complex electrical impedance of root tissue $\left(Z_{r}\right)$ can be expressed as the resultant of circuit elements:

$$
Z_{r}=\frac{R_{a}\left(R_{s}+Z_{m}\right)}{R_{a}+R_{s}+Z_{m}}
$$

Zm can be expressed as follows:

$$
Z_{m}=\frac{\cos \psi+j \sin \psi}{C_{m} \omega},
$$

where $j=\sqrt{-1}, \omega=2 \pi f, C_{m}$ is the cell membrane capacitance, and $\psi$ is a constant phase angle, $f$ is the measuring frequency. At low frequencies - when $Z_{m}$ is very high - the impedance of tissue is equal practically with the resistance of intercellular space $\left(R_{a}\right)$ and at high frequencies - at low $Z_{m}-Z_{r}$ is the parallel resultant of $R_{a}$ and $R_{s}$.

From the measured impedance after open-short correction the magnitude, $\left|Z_{r}\right|$, and the phase angle, $\phi_{r}$, of pea root impedance were determined. Approaching the root impedance $\left(\mathrm{Z}_{\mathrm{r}}\right)$ by complex non-linear squares with MATLAB program the resistance of extracellular space (apoplasm), $R_{a}$, the resistance of intracellular space (symplasm), $R_{s}$, and the cell membrane capacitance, $C_{m}$, were evaluated.

\subsection{Statistical analysis}

The values are expressed as the mean \pm S.D. of three independent replicates of each experiment. In each experiment the impedance was measured on 15-20 seedlings. The significance for the differences of the impedance parameters between control and flood treated plants was determined by ANOVA (in Duncan multiple comparison $p>0.05$ ) using SPSS 7.0 program.

\section{Results and discussion}

\subsection{Morphological changes of pea roots}

Root length of flooded seedlings remained shorter according to the length of root of flooded and aerated seedlings (Fig. 2). This observation can be explained by the reduced transfer of nutriments in oxygen-lack conditions (Tuba \& Csintalan, 1992). The flooded and aerated roots were grown quicker in comparison with roots flooded only, because of dissolved oxygen. On the bases of statistical analysis the aeration of Hoagland solution resulted in 
significantly longer and longer root at the moment of various experiments, while the root length increased slower in hydroponic solution without aeration. For seedlings flooded only and not aerated there was no significant difference in length of root during time period of experiment.

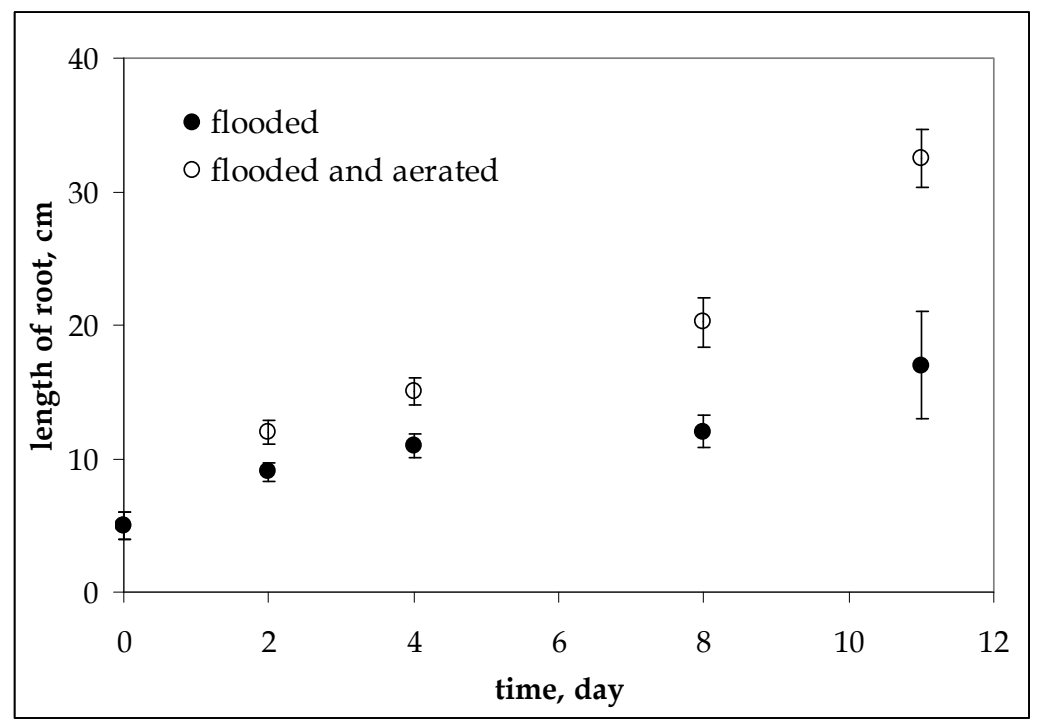

Fig. 2. The root length of three days old pea seedlings after transfer from vermiculate into hydroponic medium. Time is measured from transfer. Error bars represent SD.

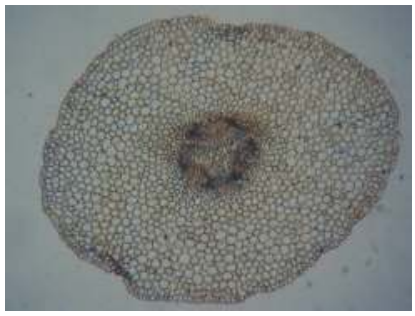

A

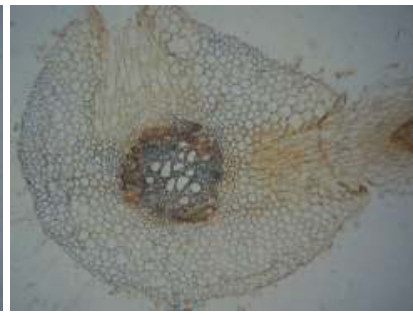

$100 \bar{\mu} \mathrm{m}$

B

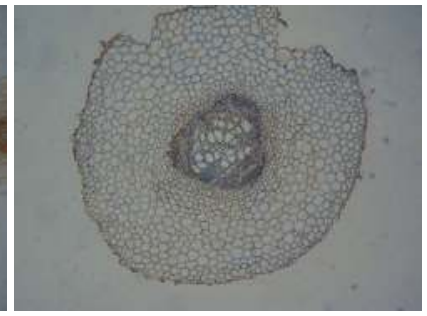

C

Fig. 3. Microscopic images of cross-section of pea roots. A - Three days old pea seedling before flooding. B - Three days old pea seedling after 11 days flooding without aeration. CThree days old pea seedlings after 11 days flooding with aeration.

The cross section images of three days old seedlings (Fig. 3A) showed the changes of the vascular cylinder of the root over time (Fig. 3B,C). The most noticeable change in the root tissue was the alteration in differentiation of tracheae of the vascular tissue in terms of numbers and size. By the end of the experiment (eleven days in Hoagland solution) the aerated controls had well developed vascular cylinder (Fig. 3C), compared to those without 
aeration (Fig. 3B), whose had less tracheae and we could not observe considerable amounts of small tracheae elements next to the large and developed ones.

Similar cavities were observed on scanning electron micrographs of vascular cylinder of primary pea roots grown under flooding (Sarkar et al., 2008). The vascular cavity had begun to form after 3 hours of flooding.

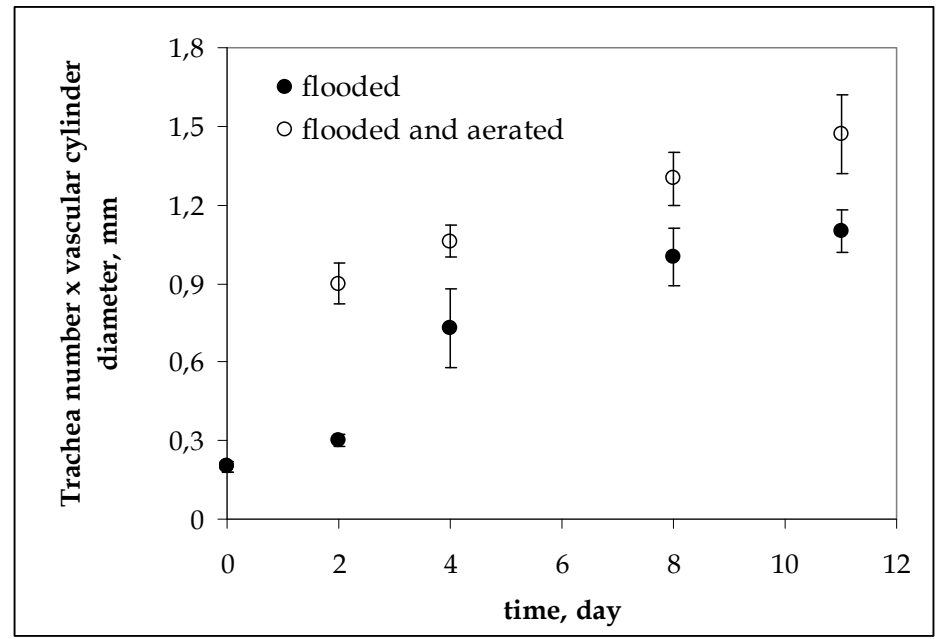

Fig. 4. Root trachea number $x$ vascular cylinder diameter of three days old pea seedlings under flooding without aeration and under flooding with aeration in the function of flooding time. Error bars represent SD.

The state of the vascular cylinder can be characterised by the numbers of tracheae and size of the vascular cylinder, so the product of the tracheae number $(\mathrm{T})$ and the diameter of the vascular cylinder (VC) was calculated as an informative parameter of the vascular cylinder (Fig. 4).

The lack of oxygen (only flooded seedlings) decreases the trachea number and vascular cylinder diameter (Fig. 4). The total area of tracheae elements of the cross sections in flooded pea seedlings with aeration was larger than in the cross sections of flooded seedlings without aeration.

\subsection{Changes in the electrical impedance parameters}

\subsubsection{Electrical impedance spectra}

The measured spectra after open and short correction were used for approaching procedure which results the impedance parameters. Typical electrical impedance spectra (in the complex plane) of the root of a seedling consist of a circular arc - at high frequencies - and a straight line - at low frequency range (Fig. 5). Similar electrical impedance curve can be taken for other biological objects, for roots of various plants (Cao et al., 2011; Rajkai et al., 2005). Generally the increase of water content in plant tissues causes the impedance decrease. 


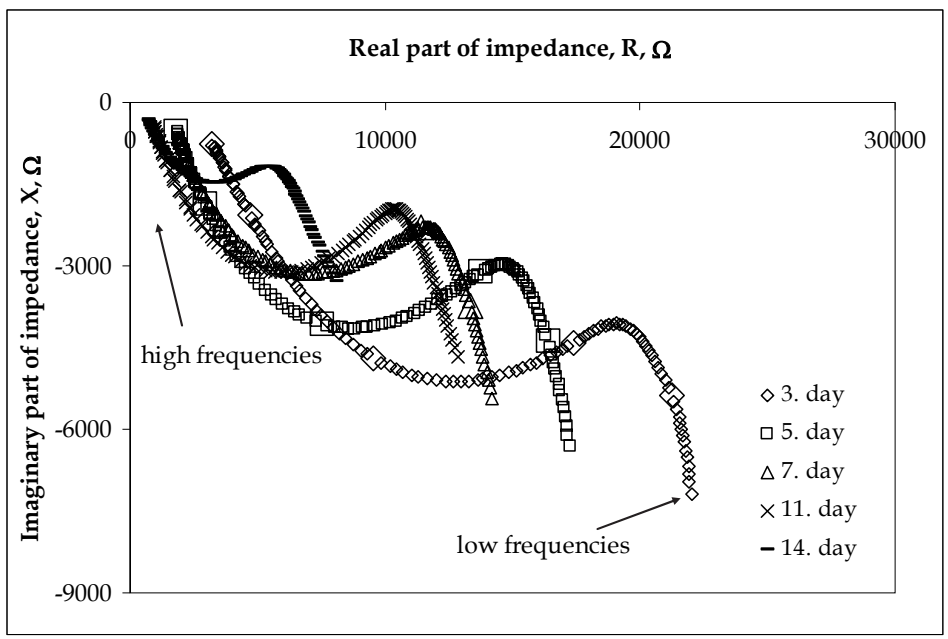

Fig. 5. Typical impedance spectra of three days old seedling at the moment of transfer from vermiculate to the half Hoagland solution and at two, four, eight and eleven days after flooding. In each spectrum the first, the second, the third, the fourth and the last enlarged point from the low frequency direction belong to frequencies of $100 \mathrm{~Hz}, 1 \mathrm{kHz}, 10 \mathrm{kHz}, 100$ $\mathrm{kHz}$ and $800 \mathrm{kHz}$, respectively.

The circular arc (Fig. 5) describes the living tissue impedance, which depends on structure and state of biological object (Grimnes \& Martinsen, 2000). The low frequency part $(10 \mathrm{~Hz}-$ $1000 \mathrm{~Hz}$ ) of the spectrum represents the electrode impedance (Macdonald, 1987). Elimination of electrode impedance is possible with a four-electrode measurement or with a correction if the impedance is measured at least with three different electrode distances (Grimnes \&Martinsen, 2000; Zhang \& Willison, 1991). In our experiments the diameter and length of seedlings were too little for four-electrode measurements and for more than one electrode distance. It can be assumed, that electrode polarization does not depend on the age of seedlings. In this case during our experiments the decreasing tendency in radius of Wessel-diagram can be thought truth.

\subsubsection{Approaching of electrical impedance spectrum of root}

For mathematical approaching the circular arc - in frequency range from $2000 \mathrm{~Hz}$ up to $1 \mathrm{MHz}$ - is used. This frequency range was used for approaching to avoid the effect of electrode impedance on parameters of tissue impedance. The measured impedance points at various frequencies were approached with modified Hayden model containing the resistance of intercellular and intracellular parts and the capacitance of cell membrane. Approaching of a typical measured spectrum with complex non-linear squares can be seen in Fig. 6. MATLAB program was used for the calculation.

The model parameters, $R_{a}, R_{s}$ and $C_{m}$ were evaluated for each seedling. The experiments were repeated three times and in one experiment the impedance spectrum of about 15-20 seedlings were measured. The average of one parameter is calculated from about $45-60$ values. 


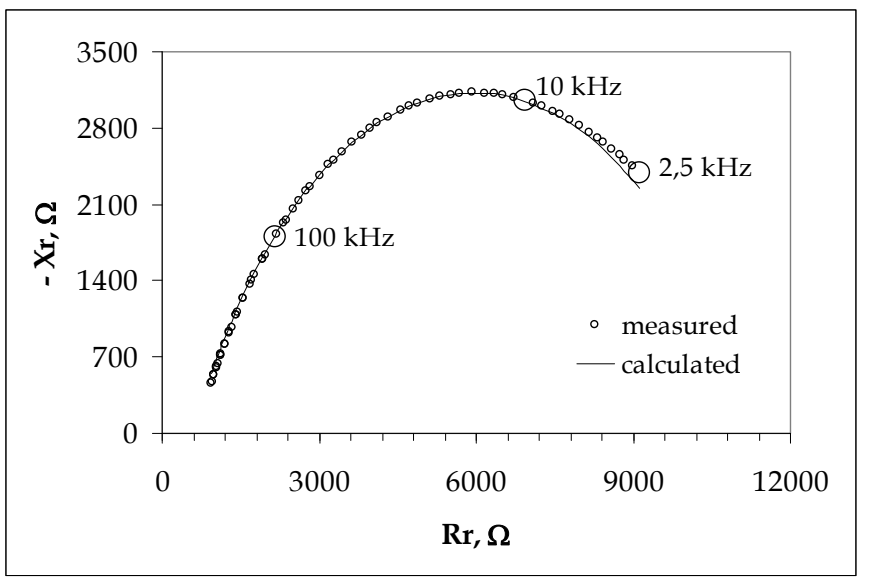

Fig. 6. Approach with complex non-linear least square method a typical measured spectrum in frequency range from $2,5 \mathrm{kHz}$ up to $1 \mathrm{MHz}$. The modified Hayden model was used for approaching. MATLAB program was used for calculations.

\subsubsection{Changes in electrical impedance parameters}

The apoplasmic resistance, $R_{a}$, of three days old seedlings grown on vermiculate has about $25 \mathrm{k} \Omega$ (Fig. 7). After transferring the seedling into the half Hoagland solution this value decreases to about $10 \mathrm{k} \Omega$. The total lack of oxygen (only flooded seedlings) results into a higher rate in $R_{a}$ decrease. In the aerated solution this decrease is slower.

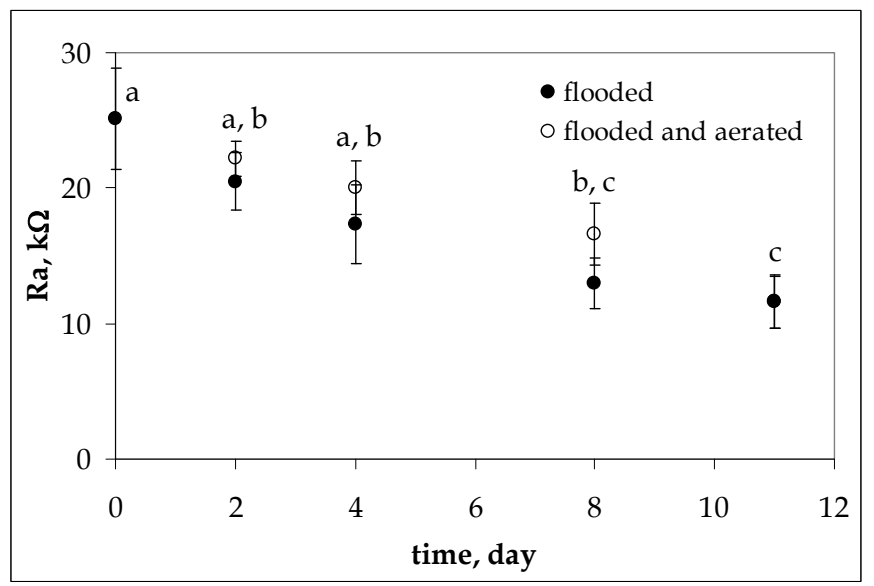

Fig. 7. Change of apoplasmic resistance $\left(R_{a}\right)$ in root of three days old pea seedlings after transfer from vermiculate into half Hoagland solution with and without aeration during eleven days. The error bars represent the standard deviation. Values designated by the same letters did not differ significantly from one another in the Duncan multiple comparison test at the $p<0.05$. 
The decrease of intercellular resistance may be the consequence of interaction of several flood-induced mechanisms with some growing processes. From our light microscopic images (Fig. 3) and from scanning electron microscopic images (Sarkar et al., 2008) the tracheae formatted under flooding with higher diameters can be consider as electrical conductor. Moreover, the natural growth phenomena of pea seedlings lead also to the formation tracheae. If the cross-section of an electrical conductor increases, the resistance becomes lower.

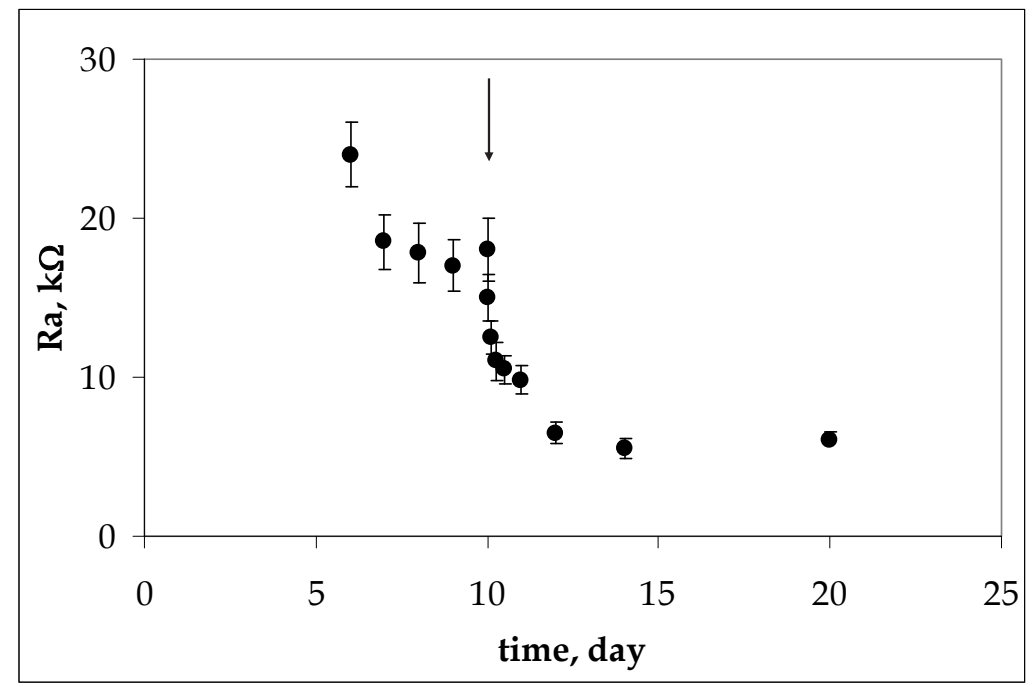

Fig. 8. Change of apoplasmic resistance $\left(R_{a}\right)$ in root of ten days old seedling during growth in vermiculate and after transfer from vermiculate into half Hoagland solution without aeration. The arrow shows the transfer. The error bars represent the standard deviation.

The intercellular resistance $\left(R_{a}\right)$ of ten days old seedlings after transfer from vermiculate into the hydroponic drastically decreases from about $20 \mathrm{k} \Omega$ down to $10 \mathrm{k} \Omega$ during some hours (Fig.8). This very quick decrease (during some hours) of apoplasm resistance is in good agreement of the observation, that the vascular cavity can be formed during three hours after flooding (Sarkar et al., 2008).

The resistance of symplasm in root of three days old pea seedlings also shows a decreasing tendency after flooding (Fig. 9). The $R_{s}$ value decreased from about $3 \mathrm{k} \Omega$ down to $0.5 \mathrm{k} \Omega$ during our experiment time period. Practically there is no difference of intracellular resistance in root of seedlings flooded with or without aeration. But there are significant differences in $R_{s}$ values of experiments following each other in time, except the two last experiments.

In the case of ten days old seedlings the intracellular resistance also drastically decreases after transfer from vermiculate to half Hoagland solution (Fig. 10). The rate of decrease is not as high as in intracellular resistance (Fig. 8). $R_{s}$ value decreased from about $1,3 \mathrm{k} \Omega$ down to $0.5 \mathrm{k} \Omega$. 


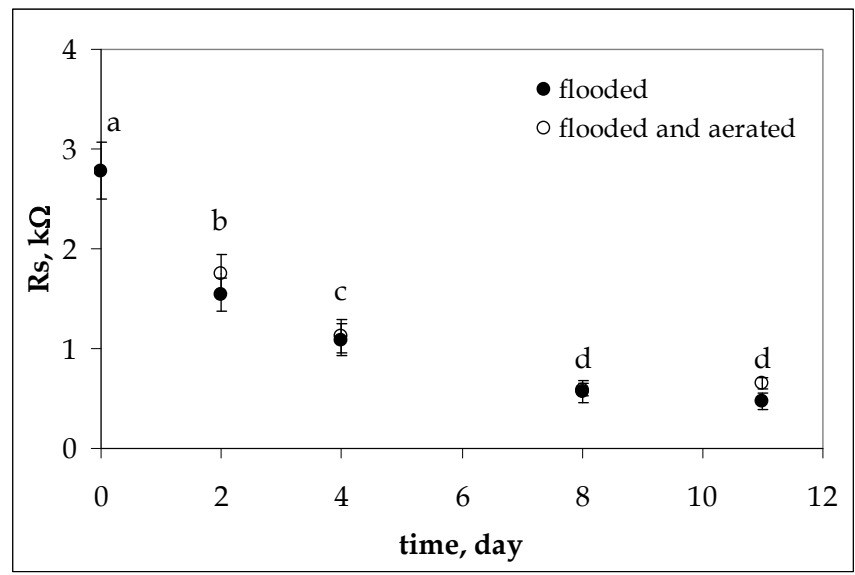

Fig. 9. Change of symplasmic resistance $\left(R_{s}\right)$ in root of three days old pea seedlings after transfer from vermiculate into half Hoagland solution with and without aeration during eleven days. The error bars represent the standard deviation. Values designated by the same letters did not differ significantly from one another in the Duncan multiple comparison test at the $p<0.05$.

Water gets into plant roots mainly via the apoplasmic route, but it can also enter cells through aquaporins - cell membrane protein channels that allow the active passage of water (Martinoia et al., 2000). The latter mechanism allows the amount of water to increase rapidly in flooded pea root tissues and this in turn increases ion mobility, which is one of the main factors affecting plant tissue impedance (Vozáry et al., 1999).

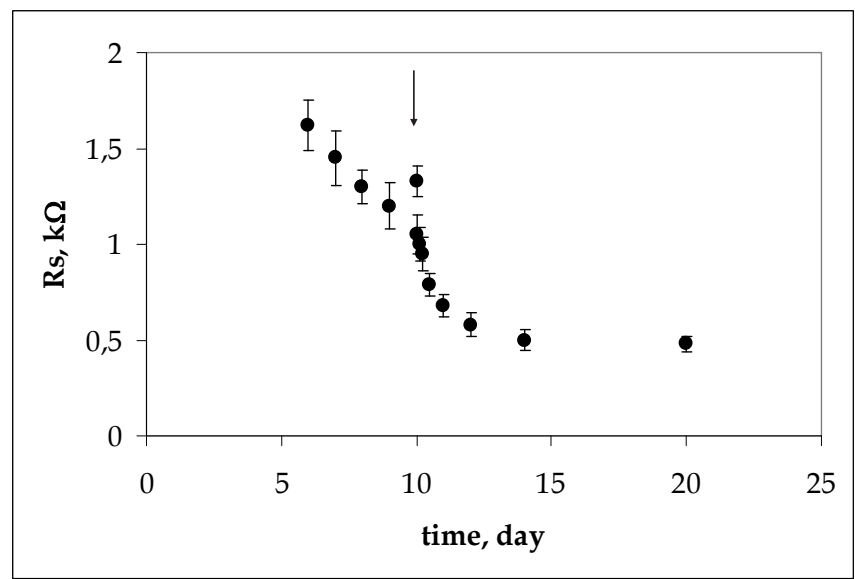

Fig. 10. Change of symplasmic resistance $\left(R_{s}\right)$ in root of ten days old seedling during growth in vermiculate and after transfer from vermiculate into half Hoagland solution without aeration. The arrow shows the transfer. The error bars represent the standard deviation. 


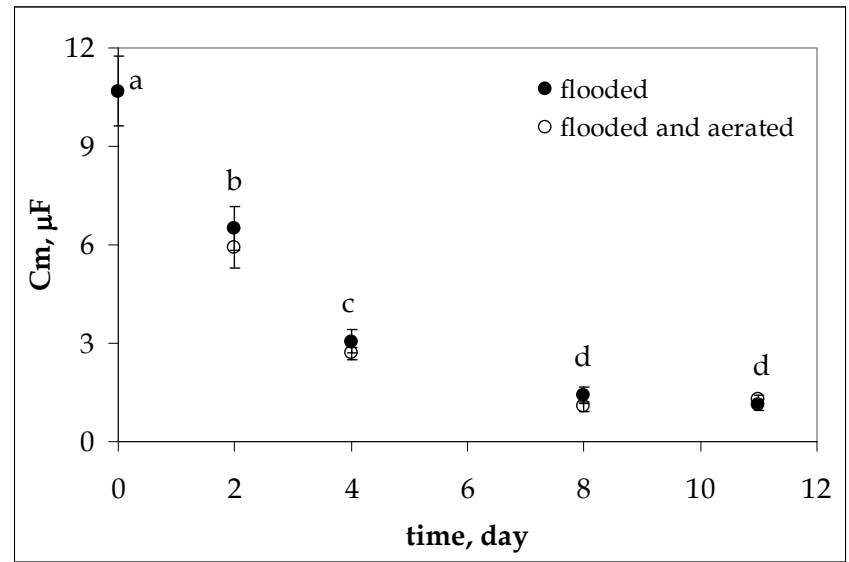

Fig. 11. Change in membrane capacitance of root in three days old pea seedlings after transfer from vermiculate to half Hoagland solution with and without aeration, during eleven days. The error bars represent the standard deviation. Values designated by the same letters did not differ significantly from one another in the Duncan multiple comparison test at the $p<0.05$.

Sudden flooding induces the growth of vacuoles, which are also part of the electrical conductor system of the cells, and this can also contribute to decreased resistance and capacitance values (Niki \& Gladish, 2001). Tissue impedance is closely related to both cellular ionic mobility (Vozáry et al., 1999) and the diameter of electrical conductors. The changes in these two factors will also lead to a decrease of symplasmic resistance and membrane capacitance values in the roots. Indeed, the decrease of membrane capacitance of root in three days old pea seedling was observed (Fig. 11) after transfer of seedlings from perlite to half Hoagland solution. The capacitance decreases from about $10 \mu \mathrm{F}$ to $1 \mu \mathrm{F}$ during the experiment period. The average value of membrane capacitance practically does not depend on the aeration of solutions.

\section{Conclusions}

Considering all these observations we conclude that parameters calculated from the measured impedance spectra constitute a non-invasive method by which it is possible to follow the changes of pea seedlings' tissue structure caused by simulated flooding. In addition, it fulfils important criteria, such as the measurement being carried out rapidly, and not requiring the processing of plant tissues. Furthermore electrical impedance measurements can be done on relatively young seedlings, so that the effects of stress agents can be detected even in the early stages of the development before visible symptoms occurred. In this developmental stage, highly sensitive environmental stress detecting methods, for example fluorescence induction measurement cannot be realised because of the lack of fully opened leaves. The method of electrical impedance measurement can be suitable for the detection of flood induced plant tissue structure changes through the alteration of $R_{a}, R_{s}$ and $C_{m}$ parameters even in the very early stage of stress evolution. 
The changes in $R_{a}, R_{s}$ and $C_{m}$ parameters consist of two different phenomena: 1 . the structural changes in vascular cylinder in root of pea seedlings caused by flood with or without aerations and 2. the structural changes in consequence of growing processes (increasing number and size of cells) far from central part of root. Parameter $R_{a}$ seems to be sensitive to existence or lack of aeration in flooded circumstances.

Considering the possible effect of electrode polarization in consequence of overlapping the impedance spectrum of electrode with the spectrum of root tissue, the concrete values of impedance parameters can be a little changed, but the decreasing tendency of $R_{a}, R_{s}$ and $C_{m}$ after flooding has to be unchanged.

On the basic of this work the development of a portable LCR meter can be realized, which can work with some fixed frequencies and with electrodes of little geometrical dimensions and more electrode distances to eliminate the electrode polarization. This potable equipment can be used in detection of structural changes in plant tissues caused by various environmental effects, for example the extreme water supply or in contrary the drought.

\section{Acknowledgment}

This work was supported by Hungarian Government Foundation

TÁMOP 4.2.1. B-09/1/KMR:

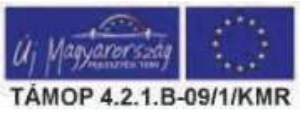

\section{References}

Cao, Y.; Repo, T.; Silvennoinen, R.; Lehto, T. \& Pelkonen, P. (2011). Analysis of the Willow Root System by Electrical Impedance Spectroscopy. Journal of Experimental Botany, Vol.62, No.1, pp. 351-358, ISSN 00220957

Greenham, C.G.; Randall, J.P. \& Ward, M.M. (1972). Impedance parameters in relation to phosphorus and calcium deficiencies in subterranean clover (Trifolium subterraneum L ). Journal of Experimental Botany, Vol.23, No.1, pp. 197-209, ISSN 00220957

Grichko, V.P. \& Glick, B.R. (2001). Ethylene and flooding stress in plants. Plant Physiology and Biochemistry, Vol.39, No.1, pp. 1-9, ISSN 0981-9428

Grimnes, S. \& Martinsen, O.G. (2000), Electrical properties of tissue. In: Bioimpedance and Bioelectricity Basics, S. Grimnes \& O.G. Martinsen (Eds.), 195-239, Academic Press, ISBN 0-12-303260-1, New York, USA

Harker, F. R. \& Maindonald, J. H. (1994). Ripening of Nectarine Fruit (Changes in the Cell Wall, Vacuole, and Membranes Detected Using Electrical Impedance Measurements). Plant Physiology, Vol.106, No.1, pp. 106-165, ISSN 0032-0889

Hayden, R.I.; Moyse, C.A.; Cadler, F.W.; Crawford, D.P. \& Fensom D.S. (1969). Electrical impedance studies on potato and alfalfa tissue. Journal of Experimental Botany, Vol.20, No.2, pp. 177-200, ISSN 00220957

Hoagland, D.R. \& Arnon, A.J. (1950). The water culture method for growing plants without soil. California Agriculture Experimental Station Circular, Vol.347, pp. 1-32, 
Honda, M. (1989). The Impedance Measurement Handbook (A Guide to Measurement Technology and Techniques), Yokogawa-Hewlett-Packard LTD., Hewlett-Packard Co., USA

Iijima, M., \& Kato, J. (2007). Combined soil physical stress of soil drying, anaerobiosis and mechanical impedance to seedling root growth of four crop species. Plant Production Science, Vol.10, No.4, pp. 451-459, ISSN 1343-943X

Luxova, M. (1986). The hydraulic safety zone at the base of barley roots. Planta, Vol.169, No.4, pp. 465-470, ISSN 0032-0935

Macdonald, J.R. (1987). Impedance spectroscopy, John Wiley and Sons ISBN 0-471-83122-0, New York, USA

Martinoia, E.; Massonneau, A. \& Frangne, N. (2000). Transport processes of solutes across the vacuolar membrane of higher plants. Plant Cell Physiology, Vol.41, No.11, pp. 1175-1186, ISSN 0032-0781

Mészáros, P.; Vozáry, E. \& Funk, D.B. (2005). Connection between moisture content and electrical parameters of apple slices during drying. Progress in Agricultural Engineering Science, Vol.1, No.1, pp. 95-121, ISSN 1786-335X

Niki, T. \& Gladish, D.K. (2001). Changes in growth and structure of pea primary roots (Pisum sativum L. cv. Alaska) as a result of sudden flooding. Plant Cell Physiology, Vol.42, No.7, pp. 694-702, ISSN 0032-0781

Pething, R. \& Kell, D. B. (1987). The passive electrical properties of biological systems: their significance in physiology, biophysics and biotechnology. Physics in Medicine and Biologyl, Vol.32, No.8, pp. 933-970, ISSN 0031-9155

Privé, J.P. \& Zhang, M.I.N. (1996). Estimating cold stress in 'Beautiful arcade` apple roots using electrical impedance analysis. Hort Technology, Vol.6, No.1, pp. 54-58, ISSN 1063-0198

Repo, T. \& Zhang, M. I. N. (1993). Modeling woody plant tissues using distributed electrical cicuit. Journal of Experimental Botany, Vol.44, No.5, pp. 977-982, ISSN 00220957

Repo, T.; Zhang, G.; Ryyppo, A. \& Rikala, R. (2000). The electrical impedance spectroscopy of Scot pine (Prunus sylvestris L.) shoots in relation to cold acclimation. Journal of Experimental Botany, Vol.51, No.12. pp. 2095-2107, ISSN 0022-0957

Rajkai, K.; Végh, K.R. \& Nacsa, T. (2005). Electrical Capacitance of Roots in Relation to Plant Electrodes, Measuring Frequency and Root Media. Acta Agronomica Hungarica, Vol. 53, No.2, pp. 197-210, ISSN 0238-0161

Ruzin S.E. (1999). Plant microtechnique and microscopy, Oxford University Press, ISBN 0-19508956-1, Oxford

Sarkar, P.; Niki, T. \& Gladish, D.K. (2008). Changes in Cell Wall Ultrastucture Induced by Sudden Flooding at $25^{\circ} \mathrm{C}$ in Pisum sativum (Fabaceae) Primary Roots. American Journal of Botany, Vol.95, No. 7, pp. 782-792 ISSN 0002-9122

Toyoda, K.; Farkas, I. \& Kojima, H. (1994). Monitoring changes in material properties of agricultural products during heating and drying by impedance spectroscopical analysis. Journal of Food Physics, Vol.2, No.1, pp. 69-98, ISSN1416-3365

Tuba, Z. \& Csintalan, Zs. (1992), The effect of pollution on the physiological process in plants. In: Biological Indicators in Environmental Protection. (M. Kovács; J. Podoni; Z. Tuba, \& G. Turcsányi, (Eds.), pp. 169-191, Publishing House of the Hungarian Academy of Sciences, ISBN 963-05-6183-2, Budapest, Hungary 
Vozáry, E.; László, P. \& Zsivánovits, G. (1999), Impedance parameter characterizing apple bruise. Annals of New York Academy of Sciences, Vol.873, pp. 421-429, ISBN 1-57331191-1

Vozáry, E.; Paine, D.H.; Kwiatkowski, J. \& Taylor, A.G. (2007). Prediction of soybean and snap bean seed germinability by electrical impedance spectroscopy. Seed Science and Technology, Vol.35, No.1, pp. 48-64, ISSN 0251-0952

Vozáry, E.; Jónás, G.; Hitka, G.; Koncz, G.; Hanula-Kövér, G. \& Benkő, P. (2009). Effect of air humidifying on impedance parameters of ice lettuce. Proceedings of International Conference on Electromagnetic Wave Interaction with Water and Moist Substances, pp. 398-404, ISBN 978-951-22-9940-9, Espoo, Finland, June 1-5, 2009

Vozáry, E. \& Benkő, P. (2010). Non-destructive determination of impedance spectrum of fruit flash under the skin. Proceedings of $14^{\text {th }}$ International Conference on Electrical Bioimpedance, Journal of Physics: Conference Series, Vol.224, 012142, ISSN 1742-6596, Gaineswille, University of Florida, Florida, USA, April 4-8, 2010, Available from: http:/ / iopscience.iop.org/1742-6596/224/1

Zhang, M.I.N. \& Willison, J.H.M. (1991). Electrical impedance analysis in plant tissues: A double shell model. Journal of Experimental Botany, Vol.42, No.11, pp. 1465-1476, ISSN 00220957

Zhang, M.I.N. \& Willison, J.H.M. (1993). Electrical impedance analysis in plant tissues: impedance measurement in leaves. Journal of Experimental Botany, Vol.44, No.8, pp. 1369-1375, ISSN 00220957 


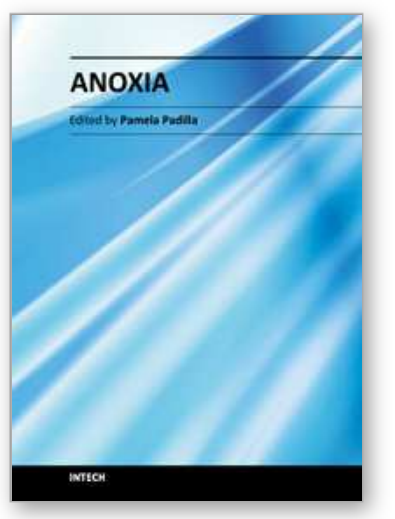

\author{
Anoxia \\ Edited by Dr. Pamela Padilla
}

ISBN 978-953-307-664-5

Hard cover, 146 pages

Publisher InTech

Published online 05, January, 2012

Published in print edition January, 2012

This book reviews how severe oxygen deprivation affects biological systems - from the molecular to the ecological level. The contributing authors come from diverse regions of the world, which proves the interest in the academic analysis of oxygen deprivation. The diversity in the experimental approach scientists take, in order to understand the influence oxygen deprivation has on living systems, is apparent throughout this book. One of the presented ideas deals with the exploration and examination of the physiological, cellular and genetic characteristics of killifish embryos and nematodes exposed to anoxia. Furthermore, the book includes material on the mechanisms regulating hypoxia and anoxia tolerance and their implications of on human health issues. Finally, new methodologies to examine oxygen deprivation and the impact of human-related activities on oxygen level, within important ecological systems such as Lake Victoria, are presented. There is no doubt that the oxygen molecule is central to every stratum of biological systems.

\title{
How to reference
}

In order to correctly reference this scholarly work, feel free to copy and paste the following:

Eszter Vozáry, Ildikó Jócsák, Magdolna Droppa and Károly Bóka (2012). Connection Between Structural Changes and Electrical Parameters of Pea Root Tissue Under Anoxia, Anoxia, Dr. Pamela Padilla (Ed.), ISBN: 978-953-307-664-5, InTech, Available from: http://www.intechopen.com/books/anoxia/connection-betweenstructural-changes-and-electrical-parameters-of-pea-root-tissue-under-anoxia

\section{INTECH}

open science | open minds

\section{InTech Europe}

University Campus STeP Ri

Slavka Krautzeka 83/A

51000 Rijeka, Croatia

Phone: +385 (51) 770447

Fax: +385 (51) 686166

www.intechopen.com

\section{InTech China}

Unit 405, Office Block, Hotel Equatorial Shanghai No.65, Yan An Road (West), Shanghai, 200040, China 中国上海市延安西路65号上海国际贵都大饭店办公楼 405 单元 Phone: +86-21-62489820

Fax: $+86-21-62489821$ 
(C) 2012 The Author(s). Licensee IntechOpen. This is an open access article distributed under the terms of the Creative Commons Attribution 3.0 License, which permits unrestricted use, distribution, and reproduction in any medium, provided the original work is properly cited. 